\title{
Effect of dietary concentrate on rumen fermentation, digestibility, and nitrogen losses in dairy cows
}

\author{
M. Agle, ${ }^{*}$ A. N. Hristov, ${ }^{, 1,2}$ S. Zaman, ${ }^{*}$ C. Schneider, ${ }^{*}$ P. M. Ndegwa, $†$ and V. K. Vaddella $†$ \\ *Department of Animal and Veterinary Science, University of Idaho, Moscow 83844 \\ †Biological Systems Engineering Department, Washington State University, Pullman 99164
}

\begin{abstract}
The objective of this experiment was to investigate the effect of level of dietary concentrate on rumen fermentation, digestibility, and $\mathrm{N}$ losses in lactating dairy cows. The experiment was a replicated $3 \times 3$ Latin square design with 6 cows and 16-d adaptation periods. Ruminal contents were exchanged between cows at the beginning of each adaptation period. Data for 2 of the diets tested in this experiment are presented here. The diets contained (dry matter basis): $52 \%$ (LowC; control) and $72 \%$ (HighC) concentrate feeds. Crude protein contents of the diets were 16.5 and $16.4 \%$, respectively. The HighC diet decreased ruminal $\mathrm{pH}$ and ammonia concentration and increased propionate concentration compared with LowC. Acetate:propionate ratio was greater for LowC than for HighC. Rumen methane production and microbial protein synthesis were unaffected by diet. Dry matter intake was similar among diets, but milk yield was increased by HighC compared with LowC (36.0 and $33.2 \mathrm{~kg} / \mathrm{d}$, respectively). Milk fat percentage and yield and total-tract apparent NDF digestibility were decreased by HighC compared with LowC. More ruminal ammonia $\mathrm{N}$ was transferred into milk protein with HighC than with LowC. Urinary $\mathrm{N}$ excretion, plasma urea $\mathrm{N}$, and milk urea $\mathrm{N}$ concentration were not affected by diet. The ammonia emitting potential of manure was similar between LowC and HighC diets. Increased concentrate proportion in the diet of dairy cows resulted in reduced ruminal ammonia concentration and enhanced ammonia utilization for milk protein synthesis. These effects, however, did not result in reduced urinary $\mathrm{N}$ losses and only marginally improved milk $\mathrm{N}$ efficiency. Increasing dietary concentrate was not a successful strategy to mitigate enteric methane production and ammonia emissions from manure.
\end{abstract}

\footnotetext{
Received December 7, 2009.

Accepted May 11, 2010.

${ }^{1}$ Corresponding author: anh13@psu.edu

${ }^{2}$ Current address: Department of Dairy and Animal Science, Pennsylvania State University, University Park 16802.
}

Key words: dietary concentrate, ammonia utilization, methane, ammonia emission

\section{INTRODUCTION}

Under normal feeding conditions, a large proportion of the dietary protein will pass through the ammonia pool before it is utilized for microbial protein synthesis in the rumen (Pilgrim et al., 1970; Nolan, 1975; Hristov et al., 2005). Ammonia utilization in the rumen is intrinsically related to carbohydrate availability (Russell et al., 1983). These classic experiments demonstrated that ruminal proteolysis and deamination will proceed to complete conversion of dietary protein to ammonia if carbohydrate availability is low. When carbohydrate availability increases, ammonia production decreases because of a direct incorporation of amino $\mathrm{N}$ into microbial protein, thus bypassing the ammonia pool (Russell et al., 1983). Hristov et al. (2005) confirmed these in vitro observations in vivo and demonstrated the importance of ruminal carbohydrate availability for efficient transfer of ruminal ammonia $\mathrm{N}$ into milk protein in dairy cows.

Ruminal ammonia N not utilized for microbial protein synthesis is likely to be excreted in urine, representing a net loss to the animal and contributing to environmental pollution (Tamminga, 1992). Volatile N loss from manure (primarily ammonia), along with ground and surface water pollution, is one of the most environmentally important public concerns related to animal agriculture today. Ammonia emitted from animal manure is a major air and water pollutant contributing to eutrophication, aerosol formation, soil acidification, and impaired visibility (USEPA, 2004). Improving the efficiency of microbial capture of ammonia in the rumen by increasing carbohydrate availability is likely to reduce urinary $\mathrm{N}$ losses and subsequently gaseous $\mathrm{N}$ emissions from cattle manure. High-energy-density diets may present another environmental benefit by reducing enteric methane emissions (Boadi et al., 2004).

We hypothesized that increased availability of ruminally fermentable energy would enhance the utilization of ammonia for microbial protein synthesis, decrease 
urinary $\mathrm{N}$ losses, and reduce the ammonia emitting potential of dairy manure. Therefore, the objectives of this study were to investigate the effect of dietary concentrate on ruminal fermentation, methane production in the rumen, and ammonia emission from manure.

\section{MATERIALS AND METHODS}

Animals involved in this study were cared for according to the guidelines of the University of Idaho Animal Care and Use Committee. The committee reviewed and approved the experiment and all procedures carried out in the study.

\section{Animals and Experimental Design}

Six multiparous Holstein cows $(660 \pm 16.4 \mathrm{~kg}$ of BW; $204 \pm 25.3$ DIM at the beginning of the trial) fitted with 10-cm ruminal cannulas (Bar Diamond, Parma, ID) were used in this experiment. Cows were randomly assigned to experimental treatments in a replicated 3 $\times 3$ Latin square design trial. Treatments were a control or low concentrate diet (LowC; $52 \%$ concentrate feeds, DM basis) and a high concentrate diet (HighC; $72 \%$ concentrate feeds, DM basis) (Table 1). The third treatment in the Latin square design was a diet formulated by Priority IAC Inc. (Manitowoc, WI); data for the Priority IAC Inc. treatment are proprietary and are not presented in this paper. The diets were formulated (NRC, 2001) to meet or exceed the energy requirements (at $25 \mathrm{~kg} / \mathrm{d} \mathrm{DMI}$ ) of a Holstein cow yielding $35 \mathrm{~kg}$ of milk/d with $3.50 \%$ milk fat and $3.10 \%$ true protein. The original diets were formulated to contain $18 \%$ CP. Because of changes in forage quality during the trial, the actual CP content of the diets was lower (Table 1). Cows were fed at 0700 and $1800 \mathrm{~h}$ (one-half of the daily allowed feed at each feeding). Each experimental period consisted of $23 \mathrm{~d}$. During the first $2 \mathrm{~d}$, dietary concentrate level was gradually increased in the HighC diet (by approximately 10 percentage units/d compared with LowC). This period was followed by a 14-d adaptation to the diet period and by $7 \mathrm{~d}$ of sampling. The LowC diet had $16 \mathrm{~d}$ of adaptation and 7-d sampling periods. On the last day of periods 1 and 2 , the ruminal contents were exchanged between cows on the LowC and HighC diets. During the adaptation periods, the cows were housed in box stalls and then moved to tie stalls for the duration of the sampling period. Feeding was ad libitum to about $5 \%$ orts. Cows had free access to fresh water during the trial. One of the cows, being in late lactation (303 DIM at the beginning of the trial), received recombinant bovine somatotropin every $14 \mathrm{~d}$ throughout the experiment. Because the bST administration period did not match experimental
Table 1. Ingredient (\% of ration DM) and chemical composition of the diets fed in the trial

\begin{tabular}{|c|c|c|}
\hline \multirow[b]{2}{*}{ Item } & \multicolumn{2}{|c|}{$\operatorname{Diet}^{1}$} \\
\hline & LowC & HighC \\
\hline \multicolumn{3}{|l|}{ Ingredient } \\
\hline Alfalfa hay ${ }^{2}$ & 6.9 & 6.8 \\
\hline Alfalfa haylage $^{3}$ & 18.0 & 14.5 \\
\hline Corn silage $^{4}$ & 21.2 & 5.3 \\
\hline Wheat straw & 1.7 & 1.7 \\
\hline Corn grain, ground & 18.0 & 37.9 \\
\hline Barley grain, rolled & 6.9 & 6.8 \\
\hline $\operatorname{SSBM}^{5}(44 \% \mathrm{CP})$ & 6.2 & 6.1 \\
\hline Cottonseed, whole with lint & 6.9 & 6.9 \\
\hline Corn dry distillers grain with soluble & 8.4 & 8.2 \\
\hline Wheat middlings & 3.4 & 3.4 \\
\hline Urea & 0.2 & 0.2 \\
\hline Mineral/vitamin/fat premix ${ }^{6}$ & 2.2 & 2.2 \\
\hline \multicolumn{3}{|l|}{ Composition. \% of DM } \\
\hline $\mathrm{CP}$ & 16.5 & 16.4 \\
\hline $\mathrm{RDP}^{7}$ & 11.4 & 11.1 \\
\hline RUP $^{7}$ & 5.2 & 5.4 \\
\hline NDF & 32.4 & 26.3 \\
\hline $\mathrm{NE}_{\mathrm{L}}, \mathrm{Mcal} / \mathrm{kg}^{7}$ & 1.56 & 1.59 \\
\hline Starch $^{8}$ & 21.3 & 29.6 \\
\hline $\mathrm{NFC}^{7}$ & 42.0 & 48.6 \\
\hline $\mathrm{Ca}^{7}$ & 0.8 & 0.7 \\
\hline $\mathrm{P}^{7}$ & 0.4 & 0.4 \\
\hline
\end{tabular}

${ }^{1}$ LowC $=$ low-concentrate $(52 \%$, DM basis $) \operatorname{diet~(control);~HighC~}=$ high-concentrate (72\%, DM basis) diet.

${ }^{2}$ Alfalfa hay contained (as \% of DM) $48 \% \mathrm{NDF}$ and $16 \% \mathrm{CP}$.

${ }^{3}$ Alfalfa haylage was $32 \%$ DM and contained (as \% of DM) $44 \%$ NDF and $18 \% \mathrm{CP}$.

${ }^{4}$ Corn silage was $30 \%$ DM and contained (as \% of DM) $42 \%$ NDF and $7 \% \mathrm{CP}$

${ }^{5}$ Soybean meal, solvent extracted.

${ }^{6}$ Land O'Lakes (St. Paul, MN). The premix contained (\%, as-is basis) fat nugget, 42; calcium carbonate, 17.2; sodium sesquicarbonate, 7.8 wheat middlings, 7.5; corn grain, ground, 7.1; salt, 6.3; MetaSmart (Adisseo USA Inc., Alpharetta, GA), 5.1; magnesium oxide, 4.5; trace mineral/vitamin premix, 2.5. Composition (DM basis): fat, 18.9\%; Ca, 7.4\%; Na, 5.1\%; P, 0.23\%; Mg, 2.77\%, S, 0.21\%; Cu, 488 mg/kg; Zn, $2,454 \mathrm{mg} / \mathrm{kg} ; \mathrm{Mn}, 77.1 \mathrm{mg} / \mathrm{kg} ; \mathrm{Fe}, 464 \mathrm{mg} / \mathrm{kg} ; \mathrm{Se}, 8.15 \mathrm{mg} / \mathrm{kg}$; Co, 2.3 $\mathrm{mg} / \mathrm{kg}$; I, $21.0 \mathrm{mg} / \mathrm{kg}$; vitamin A, 148,016 IU/kg; vitamin D, 23,122 $\mathrm{IU} / \mathrm{kg}$; and vitamin E, $960 \mathrm{IU} / \mathrm{kg}$.

${ }^{7}$ Estimated based on NRC (2001).

${ }^{8}$ See Material and Methods for analysis.

period, there is a remote possibility of interference of the hormonal treatment with the measurements for this particular cow. Data to verify this effect, however, were not collected.

\section{Sampling and Measurements}

Individual forage, TMR, and refusals samples were collected daily, and concentrate feeds were sampled weekly. Samples were composited (by period and cow) and analyzed for $\mathrm{DM}\left(65^{\circ} \mathrm{C}\right.$ in a forced-air oven, dried to a constant weight) and ash/OM (AOAC, 2000), N (Foley et al., 2006), NDF (Van Soest et al., 1991), and 
starch (starch assay kit, Megazyme International Ireland Ltd., Wicklow, Ireland; McCleary et al., 1994). A heat-stable $\alpha$-amylase was used in the NDF analysis. Sodium sulfite was not used in the analysis and NDF was expressed inclusive of residual ash. Composite TMR samples were also analyzed for acid-insoluble ash (AIA; Van Keulen and Young, 1977) as a digestibility marker.

Ruminal ammonia $\mathrm{N}$ was labeled through a pulse-dose of $2 \mathrm{~g} / \mathrm{cow}$ of 99 atom percent excess (APE) ${ }^{15} \mathrm{NH}_{4} \mathrm{Cl}$ (Cambridge Isotope Laboratories Inc., Andover, MA) dissolved in $5 \mathrm{~L}$ of McDougall's buffer (McDougall, 1948). The rumens of the cows were emptied in large carts before the a.m. feeding on $\mathrm{d} 15$ of each period and weighed. A background ruminal sample was then collected, ${ }^{15} \mathrm{NH}_{4} \mathrm{Cl}$ and Co-EDTA $(1 \mathrm{~L} / \mathrm{cow}$, equivalent of $2.5 \mathrm{~g}$ of $\mathrm{Co} /$ cow; Udén et al., 1980) were added and thoroughly mixed with the ruminal contents, a $0-\mathrm{h}$ sample was collected, and the ruminal contents were returned to the rumen of the cows. Cobalt-EDTA was used as a ruminal liquid passage rate marker.

Whole ruminal contents samples were collected at 1 , $2,4,6,8,10,14,18$, and $24 \mathrm{~h}$ following the a.m. feeding on d 17 of each experimental period. Ruminal samples were collected from 4 locations in the rumen and the reticulum (approximately $250 \mathrm{~g}$ each), composited, and analyzed for DM and ${ }^{15} \mathrm{~N}$ enrichment of the ammonia $\mathrm{N}$ and bacterial $\mathrm{N}$. Aliquots of the rumen samples were filtered through cheesecloth and centrifuged $(20,000 \times$ $g$ for $15 \mathrm{~min}$ at $4^{\circ} \mathrm{C}$ ) and the supernatant fluid was analyzed for Co (Iris ICP atomic emission spectrophotometer, Thermo Jarrell Ash Corp., Franklin, MA). The fractional outflow rate of the ruminal fluid was calculated as Ln-transformed Co concentrations plotted against time. Aliquots of the rumen cheesecloth filtrates were immediately analyzed for $\mathrm{pH}$, and processed for analyses of ammonia and total free amino acids (TFAA; Hristov et al., 1999), VFA (Foley et al., 2006), and polysaccharide-degrading enzyme [carboxymethylcellulase (CMCase), amylase, and xylanase] activities (Hristov et al., 1998). Individual ruminal samples were analyzed for ammonia and $\mathrm{pH}$; the remaining analyses were performed on composite (volume base, per cow and period) samples.

Methane production in the rumen was measured utilizing the sulfur hexafluoride $\left(\mathrm{SF}_{6}\right)$ tracer technique (Johnson et al., 1994). The $\mathrm{SF}_{6}$ permeation tubes were prepared by K. Johnson (Washington State University, Pullman). The tubes were placed in the reticulum of the cows on d 15 of period 1 and remained there for the duration of the study. Gas samples for methane analysis were collected directly from the rumen through modified rumen cannula lids (Hristov et al., 2009). Sampling started $2 \mathrm{~h}$ after the morning feeding and gas samples were collected every hour for $6 \mathrm{~h}$; that is, at 2 , $3,4,5$, and $6 \mathrm{~h}$ after the morning feeding. Gas samples were analyzed for methane and $\mathrm{SF}_{6}$ using gas-liquid chromatography (Hristov et al., 2009). Production of methane was calculated as the release rate of $\mathrm{SF}_{6}$ times the ratio of the concentration of methane to $\mathrm{SF}_{6}$ in the ruminal headspace (Johnson et al., 1994).

Fecal samples (400 g per sampling) were collected from the rectum or the ground, when fresh, during d 16 and 17 of each sampling period at 0900,1500 , and 2100 $\mathrm{h}(\mathrm{d} 16)$, and at 0300, 0600, 1200, 1800 (d 17), and 0000 $\mathrm{h}$ (d 18). Samples were dried at $65^{\circ} \mathrm{C}$ in a forced-air oven to constant weight, composited per animal and period, and ground through a 1-mm sieve. Samples were analyzed for ash/OM, N, NDF, starch, and AIA. Apparent total-tract digestibility was estimated using AIA as an intrinsic digestibility marker (Foley et al., 2006). At each sampling, a second fecal sample (approximately 300 g) was collected, composited (per cow and period), and frozen immediately $\left(-80^{\circ} \mathrm{C}\right)$ for analysis of ammonia emitting potential of manure.

Total urine was collected during the last $4 \mathrm{~d}$ of each period. Urinary catheters (22 French, $75 \mathrm{~mL}, \mathrm{C}$. R. Bard Inc., Covington, GA) were positioned in the cows $24 \mathrm{~h}$ before initiation of the urine collection. Urine samples were acidified during collection to a $\mathrm{pH}<3.0$ by addition of $2 \mathrm{M} \mathrm{H}_{2} \mathrm{SO}_{4}$. Aliquots were diluted 1:10 with distilled water, stored frozen at $-20^{\circ} \mathrm{C}$, and later analyzed for N, allantoin (Chen, 1989), and uric acid (Uric acid kit 1051, Stanbio Laboratory San Antonio, TX). Urinary excretion of allantoin and uric acid was used to estimate duodenal microbial protein flow. At the beginning of each urine collection period, an unacidified urine sample (approximately $2 \mathrm{~L}$ ) was collected from each cow and frozen immediately $\left(-80^{\circ} \mathrm{C}\right)$ for analysis of ammonia emitting potential of manure.

The ammonia emitting potential of manure resulting from the experimental diets was measured in laboratory-scale postcollection simulated storages with appropriate instrumentation. This laboratory system, which was adapted from similar studies (Shi et al., 2001; Misselbrook et al., 2005), consisted of a manurestorage container, an acid bottle to trap the emitted ammonia, a flow meter to regulate sweep-air, and a vacuum pump to pull air through the system. Air to facilitate and carry emitted ammonia from the manure storage headspace was drawn using the vacuum pump at a flow rate of $1 \mathrm{~L} / \mathrm{min}$. The air carrying emitted ammonia was bubbled through a previously calibrated $0.2 \mathrm{M}$ sulfuric acid bottle to trap ammonia (Ndegwa et al., 2009). Acid samples for the analysis of the trapped ammonia were collected every day during the first week and every other day during the second week. Samples were immediately analyzed for ammonia concentration 
using standard methods (APHA, 1998). The manures for these analyses were reconstituted from the respective samples of feces and urine that had previously been collected separately and frozen. Prior to reconstitution, the frozen feces and urine samples were allowed to thaw at room temperature. The feces and urine were then mixed in the ratio of $1.7: 1$, on a weight basis, to reconstitute the manure. This excretion ratio of feces:urine in lactating dairy cows was established in previous studies (Vander Pol et al., 2008a, b).

Milk yield data were collected daily (p.m. and a.m. milkings). Data for the last week of each experimental period were used in the statistical analysis. Milk samples for composition analyses (fat, true protein, and MUN; Washington DHIA, Burlington, WA) were collected during the intensive 0 to $143 \mathrm{~h}$ milking (see following text). A composite sample was analyzed and used to calculate FCM, milk $\mathrm{NE}_{\mathrm{L}}$ yield, and milk fat and protein yields. Following the ${ }^{15} \mathrm{~N}$ dose, cows were milked at 0 (background), 5, 10, 15, 20, 25, 30, 35, 40, $45,50,55,60,65,70,75,80,85,90,95,107,119,131$, and $143 \mathrm{~h}$. At each milking, milk weights were recorded and milk samples were collected for analysis of ${ }^{15} \mathrm{~N}$ enrichment of milk protein (Hristov and Ropp, 2003).

On d 20 of each experimental period, blood samples were collected from the tail vein/artery before $(0 \mathrm{~h})$ and $6 \mathrm{~h}$ after the a.m. feeding. Plasma was collected after centrifugation at $1,500 \times g$ for $40 \mathrm{~min}$, frozen at $-40^{\circ} \mathrm{C}$, and later analyzed for urea N (Urea Nitrogen kit, Ct. No. 640-8; Sigma Diagnostics, St. Louis, MO).

Body weight of the cows was recorded at the beginning and at the end of the experiment and at the beginning of periods 2 and 3 .

\section{Calculations}

Pool size of ruminal ammonia $\mathrm{N}$, areas under the ${ }^{15} \mathrm{~N}$-enrichment (APE) curves for ruminal ammonia, bacterial (BN), and milk protein N (MPN), and the proportions of MPN originating from $\mathrm{BN}$ and ammonia $\mathrm{N}$ and the proportion of $\mathrm{BN}$ originating from ruminal ammonia $\mathrm{N}$ were calculated as described elsewhere (Hristov et al., 2005). The average adjusted $\mathrm{r}^{2}$ for the ruminal ammonia and $\mathrm{BN}$ models were $0.997 \pm 0.0011$ and $0.90 \pm 0.007$, respectively. The average proportion of the variance explained by the MPN model (regression sum of squares $\div$ uncorrected total sum of squares) was $0.98 \pm 0.001$. Irreversible loss, ruminal flux, ammonia recycling, and the efficiency of utilization of ruminal ammonia $\mathrm{N}$ for microbial protein synthesis were calculated as described in Hristov et al. (2005).

The cumulative amount of ${ }^{15} \mathrm{~N}$ secreted in milk protein (as percentage of ${ }^{15} \mathrm{~N}$ dosed) was fitted to a single rectangular 2-parameter hyperbola model, and the estimated maximum secretion and overall secretion lines were compared among treatments using dummy variable regression technique (PROC NLIN, SAS Institute Inc., Cary, NC; Hristov et al., 2005). The average proportion of the variance explained by the model (regression sum of squares $\div$ uncorrected total sum of squares) was $0.93 \pm 0.029$.

Urinary purine derivatives (PD) excretion was used to estimate duodenal MN flow assuming that (1) absorption of microbial purine bases $(\mathrm{mmol} / \mathrm{d})=(\mathrm{PD}$ $\left.-0.385 \times \mathrm{BW}^{0.75}\right) \div 0.85$, where $\mathrm{PD}$ is the urinary $\mathrm{PD}$ excretion (allantoin and uric acid; $\mathrm{mmol} / \mathrm{d}$ ), 0.385 $\mathrm{mmol} / \mathrm{kg} \mathrm{BW}^{0.75}$ is a correction for endogenous PD, and 0.85 is a recovery coefficient (Verbic et al., 1990) and (2) duodenal MN flow $(\mathrm{g} \mathrm{N} / \mathrm{d})=$ (absorbed microbial purine bases $\times 70) \div(0.83 \times 0.134 \times 1,000)$, where 70 is the $\mathrm{N}$ content of purines $(\mathrm{mg}$ of $\mathrm{N} / \mathrm{mmol}$; Chen et al., 1992) and 0.134 is the ratio of purine $\mathrm{N}$ to total $\mathrm{N}$ in rumen microorganisms assumed based on the data of Valadares et al. (1999) and a digestibility coefficient of 0.83 for microbial purines (Chen et al., 1992).

\section{Statistical Analysis}

Data for 2 of the 3 treatments in this experiment were analyzed using the PROC MIXED procedure of SAS (2003; SAS Institute). Intake, digestibility, rumen fermentation data (except $\mathrm{pH}$, ammonia concentration, and methane production), urinary excretions, milk yield and composition, some of the ${ }^{15} \mathrm{~N}$-enrichment data, and end-point ( $d$ 15) cumulative ammonia emission from manure data were analyzed by ANOVA according to a Latin square design. Milk composition during the continuous milking was used in the statistical analysis and to calculate FCM, milk $\mathrm{NE}_{\mathrm{L}}$ yield, and milk fat and protein yields. The model used was

$$
\mathrm{Y}_{\mathrm{ijkl}}=\mu+\mathrm{G}_{\mathrm{i}}+\mathrm{C}(\mathrm{G})_{\mathrm{ij}}+\mathrm{P}_{\mathrm{k}}+\tau_{\mathrm{l}}+\mathrm{e}_{\mathrm{ijkl} \mathrm{l}},
$$

where $\mu$ is the overall mean, $G_{i}$ is the group, $C(G)_{i j}$ is the cow within group, $P_{k}$ is the kth period, $\tau_{1}$ is the lth treatment, with the error term $\mathrm{e}_{\mathrm{ijk}}$ assumed to be normally distributed with mean $=0$ and constant variance. Group and cow within group were random effects, whereas all other effects were fixed.

Ruminal $\mathrm{pH}$ and ammonia concentration, methane production, and ${ }^{15} \mathrm{~N}$ enrichment of ammonia $\mathrm{N}, \mathrm{BN}$, and MPN data were analyzed as repeated measures in a Latin square design, assuming an autoregressive [1] covariance structure. The model used was

$$
\begin{aligned}
Y_{\mathrm{ijklm}}=\mu+ & \mathrm{G}_{\mathrm{i}}+\mathrm{C}(\mathrm{G})_{\mathrm{ij}}+\mathrm{P}_{\mathrm{k}}+\tau_{\mathrm{l}}+\mathrm{D}_{\mathrm{m}} \\
& +\tau \mathrm{D}_{\mathrm{lm}}+\mathrm{e}_{\mathrm{ijklm}},
\end{aligned}
$$


where $\mu$ is the overall mean, $G_{i}$ is the group, $C(G)_{i j}$ is the cow within group, $\mathrm{P}_{\mathrm{k}}$ is the kth period, $\tau_{\mathrm{l}}$ is the lth treatment, $D_{m}$ is the time effect, $\tau D_{l m}$ is the treatment $\times$ time interaction with the error term $e_{i j k l m}$ assumed to be normally distributed with mean $=0$ and constant variance. Group and cow within group were random effects, whereas all other effects were fixed.

Cumulative ammonia emission from manure data fitted well a linear model (adjusted $\mathrm{r}^{2}=0.99$ ) and were analyzed as linear regression (cumulative ammonia emission, $\mathrm{mg}$ of $\mathrm{N}=$ intercept + slope $\times$ incubation day; PROC GLM, SAS Institute).

Statistical differences were declared at $P \leq 0.05$. Differences between treatments at $P \leq 0.10$ were considered as a trend toward significance.

\section{RESULTS}

Diets had similar ingredient and chemical composition, except for the higher concentration of starch and NFC and lower NDF (Table 1) in HighC compared with LowC. At the DMI and level of production observed in the study, all diets supplied $\mathrm{NE}_{\mathrm{L}}$ in excess of requirements (according to NRC, 2001). The diets supplied 16 and $11 \%$ RDP (LowC and HighC, respectively) above requirements and were adequate in MP supply $(+4$ and $+1 \%$, respectively).

Ruminal $\mathrm{pH}$ was decreased $(P=0.048)$ by HighC compared with LowC (Table 2 ). Treatment $\times$ time of sampling interaction was also significant $(P=0.042)$ for rumen $\mathrm{pH}$. Diet HighC had consistently lower $\mathrm{pH}$ throughout the sampling cycle, except before and in the early hours after feeding (Figure 1). Concentration of ruminal ammonia was lower $(P=0.018)$ for HighC compared with LowC. Treatment $\times$ time of sampling interaction was significant $(P=0.002)$. Diet HighC had lower ammonia concentration at time points 1,2 , and $4 \mathrm{~h}$ after feeding (Figure 2). Ruminal ammonia N pool size immediately before feeding (i.e., at time $0 \mathrm{~h}$ ) and ruminal TFAA concentration were similar between the 2 diets. Concentration of propionate in ruminal fluid was increased $(P=0.008)$ by HighC compared with LowC. There was no effect of diet on concentration of other VFA, except for a trend $(P=0.08)$ for lowered isovalerate by HighC. The greater concentration of propionate with HighC resulted in reduced $(P=$ $0.02)$ acetate:propionate ratio compared with LowC. Polysaccharide-degrading activities of ruminal contents were not affected by diet. Ruminal methane production and concentration (data not shown) were similar among diets. The numerically lower methane production rate with HighC could not reach statistical significance because of large variability in the data. There was no diet $\times$ time of sampling interaction for methane production. Fractional outflow rate of ruminal fluid and urinary excretion of allantoin, uric acid, and consequently total $\mathrm{PD}$ and estimated ruminal outflow of MN were not different between the 2 diets.

Milk yield was increased $(P=0.041)$ by HighC compared with LowC (Table 3). Feed efficiency (milk yield $\div$ DMI $)$ was greater $(P=0.022)$ for HighC compared with LowC. Milk fat percentage, yield, and $4 \%$ FCM were reduced $(P<0.02)$ by HighC. Concentration of milk true protein was not affected by diet, but protein and $\mathrm{N}$ yields tended to be increased $(P=0.072)$ by HighC compared with LowC. This led to a trend $(P=$ 0.062 ) for greater milk $\mathrm{N}$ efficiency (milk $\mathrm{N}$ secretion as proportion of $\mathrm{N}$ intake) with the HighC diet. The 2 diets had similar milk $\mathrm{NE}_{\mathrm{L}}$ yield, efficiency, and MUN and PUN (numerically lower for HighC, $P=0.11$ ) concentrations. Milk lactose concentration and cow BW were not different between the diets. Intakes of DM, $\mathrm{OM}$, and $\mathrm{N}$ were similar between the diets. Intake of NDF was lower $(P=0.010)$ and that of starch was higher $(P=0.002)$ for HighC compared with LowC. Total-tract apparent digestibilities of DM, OM, N, and starch were not affected by diet. Digestibility of NDF was decreased $(P=0.047)$ by HighC compared with LowC.

The diets had no effect on $\mathrm{N}$ losses with urine and feces (Table 4). Overall, ${ }^{15} \mathrm{~N}$ enrichment of ruminal ammonia $\mathrm{N}$, bacterial $\mathrm{N}$, and MPN were not affected by $\operatorname{diet}$ (Table 5 and Figures 3, 4, and 5). The significant $(P=0.010)$ interactions between treatment and time of sampling for ammonia $\mathrm{N}$ was due only to the lower initial enrichment with HighC versus LowC as a result of the smaller ruminal ammonia $\mathrm{N}$ pool with the former diet. Areas under the ${ }^{15} \mathrm{~N}$ curve for ruminal ammonia $\mathrm{N}$ and MPN were not affected by diet. The cumulative secretion of ${ }^{15} \mathrm{~N}$ in milk protein during the $143 \mathrm{~h}$ of milk sampling was greater for HighC compared with LowC $(P=0.009$; Figure 6$)$. The theoretical maximum of ${ }^{15} \mathrm{~N}$ secreted in milk protein was not affected by diet. The proportions of $\mathrm{BN}$ originating from ammonia $\mathrm{N}$ and MPN originating from ammonia and $\mathrm{BN}$ and the irreversible loss of ruminal ammonia $\mathrm{N}$ were similar between the diets. Ruminal ammonia $\mathrm{N}$ flux (absolute or as proportion of $\mathrm{N}$ intake) was drastically reduced $(P=0.011)$ by HighC compared with LowC. The recycled ammonia $\mathrm{N}$ and estimated utilization of ruminal ammonia $\mathrm{N}$ for microbial protein synthesis were not affected by diet.

The ammonia emitting potential of manure (cumulative ammonia $\mathrm{N}$ emissions measured in a closed-chamber system) from HighC was greater than that of manure from LowC $(P<0.001 ;$ Figure 7$)$. The end-point (d 15) 
Table 2. Effect of dietary concentrate on rumen fermentation and urinary excretion of purine derivatives in dairy cows (least squares means; $\mathrm{n}=120$, rumen $\mathrm{pH}$ and ammonia data; $\mathrm{n}=54$, rumen methane; $\mathrm{n}=12$, all other variables)

\begin{tabular}{|c|c|c|c|c|}
\hline Item & LowC $^{1}$ & $\operatorname{HighC}^{1}$ & SEM & $P$-value \\
\hline \multicolumn{5}{|l|}{ Rumen } \\
\hline $\mathrm{pH}$ & 6.14 & 6.04 & 0.044 & $0.048^{2}$ \\
\hline $\mathrm{NH}_{3}, \mathrm{~m} M$ & 7.4 & 6.5 & 0.23 & $0.018^{3}$ \\
\hline Rumen $\mathrm{NH}_{3}-\mathrm{N}$ pool $(0 \mathrm{~h}){ }^{4} \mathrm{~g}$ & 6.9 & 7.8 & 1.32 & 0.28 \\
\hline TFAA, ${ }^{5} \mathrm{~m} M$ & 5.6 & 5.0 & 0.38 & 0.40 \\
\hline Total VFA, $\mathrm{m} M$ & 89.4 & 91.4 & 3.79 & 0.73 \\
\hline Acetate & 55.1 & 49.3 & 2.71 & 0.30 \\
\hline Propionate & 17.9 & 28.4 & 1.69 & 0.008 \\
\hline Isobutyrate & 0.85 & 0.70 & 0.047 & 0.17 \\
\hline Butyrate & 11.6 & 9.3 & 0.98 & 0.28 \\
\hline Isovalerate & 1.59 & 1.21 & 0.10 & 0.08 \\
\hline Valerate & 2.37 & 2.59 & 0.29 & 0.46 \\
\hline Acetate:propionate & 3.2 & 1.8 & 0.19 & 0.02 \\
\hline \multicolumn{5}{|l|}{ PSD activities ${ }^{6}$} \\
\hline Carboxymethylcellulase & 71.7 & 79.2 & 5.51 & 0.42 \\
\hline Xylanase & 34.5 & 32.0 & 2.04 & 0.51 \\
\hline Amylase & 106.5 & 143.4 & 19.38 & 0.23 \\
\hline Methane production rate, $\mathrm{g} / \mathrm{h}$ & 3.4 & 1.5 & 0.90 & 0.28 \\
\hline Liquid phase FOR, ${ }^{7} \% / \mathrm{h}$ & 24.5 & 28.0 & 1.33 & 0.15 \\
\hline \multicolumn{5}{|l|}{ Urinary $\mathrm{PD},{ }^{8} \mathrm{mmol} / \mathrm{d}$} \\
\hline Allantoin & 490 & 503 & 20.3 & 0.37 \\
\hline Uric acid & 53 & 63 & 4.4 & 0.14 \\
\hline Total PD & 544 & 566 & 22.5 & 0.53 \\
\hline $\mathrm{MN},{ }^{9} \mathrm{~g} / \mathrm{d}$ & 366 & 383 & 16.8 & 0.54 \\
\hline
\end{tabular}

${ }^{1}$ LowC $=$ low-concentrate $(52 \%$, DM basis) diet (control); HighC = high-concentrate $(72 \%$, DM basis) diet.

${ }^{2}$ Treatment $\times$ time interaction, $P=0.042$.

${ }^{3}$ Treatment $\times$ time interaction, $P<0.001$.

${ }^{4}$ Rumen ammonia $\mathrm{N}$ pool size (g) at time 0 h estimated from ruminal evacuation data and ammonia concentration in ruminal fluid.

${ }^{5}$ Total free AA.

${ }^{6} \mathrm{PSD}=$ polysaccharide-degrading activities; expressed as nanomoles of reducing sugars as glucose released per milliliter of ruminal fluid per minute.

${ }^{7} \mathrm{FOR}=$ fractional outflow rate.

${ }^{8}$ Excretion of urinary purine derivatives (PD).

${ }^{9}$ Estimated microbial $\mathrm{N}$ outflow from the rumen [based on urinary PD excretion; see Materials and Methods].

cumulative ammonia $\mathrm{N}$ emission and rate of emission were also lower $(P=0.029$ and $P<0.001$, respectively $)$ for LowC than for HighC.

\section{DISCUSSION}

Our hypothesis in this experiment was that providing abundant energy substrate to the ruminal microorganisms would improve the efficiency of ruminal fermentation and thus enhance the capture of ruminal ammonia into microbial protein. Past research has clearly demonstrated that carbohydrate availability determines the rate of microbial growth in the rumen (Isaacson et al., 1975; Strobel and Russell, 1986) and efficiency of ruminal ammonia utilization (Newbold and Rust, 1992; Hristov et al., 1997). If energy is limiting, ruminal microorganisms degrade feed proteins to ammonia (Russell et al., 1983), and microbial ammonia uptake is suppressed (Nocek and Russell, 1988; Hristov et al., 1997). Current feeding systems for dairy cows directly

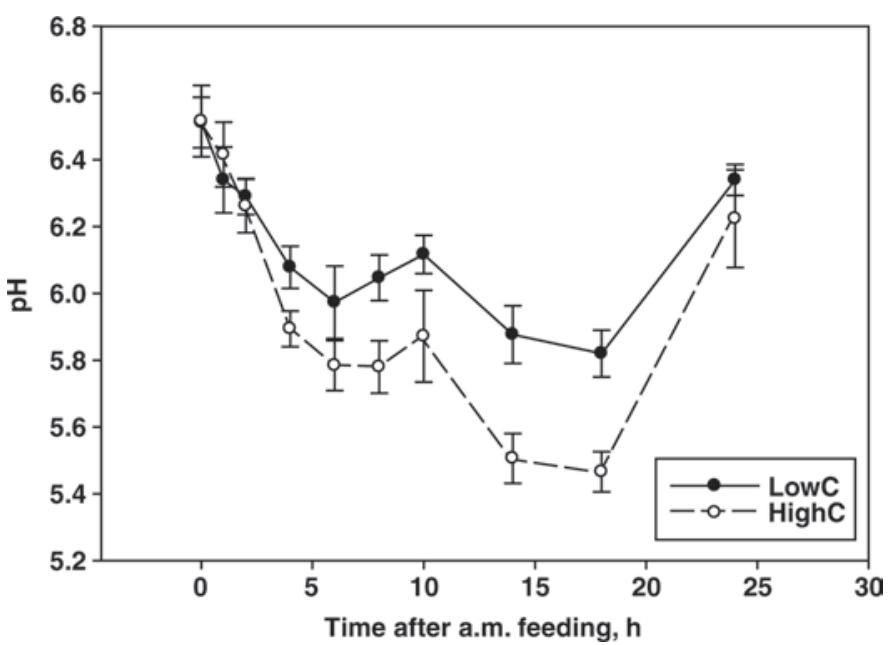

Figure 1. Effect of dietary concentrate on ruminal $\mathrm{pH}$ in dairy cows (means $\pm \mathrm{SE} ; \mathrm{n}=120)$. LowC $=$ low-concentrate $(52 \%$, DM basis) diet (control); HighC $=$ high-concentrate $(72 \%, \mathrm{DM}$ basis $)$ diet. Overall treatment effect, $P=0.048$; treatment $\times$ time interaction, $P$ $=0.042$. 
Table 3. Effect of dietary concentrate on milk yield and composition, plasma urea $\mathrm{N}$ concentration, BW, intake, and total-tract apparent digestibility of nutrients in dairy cows (least squares means; $\mathrm{n}=12$ )

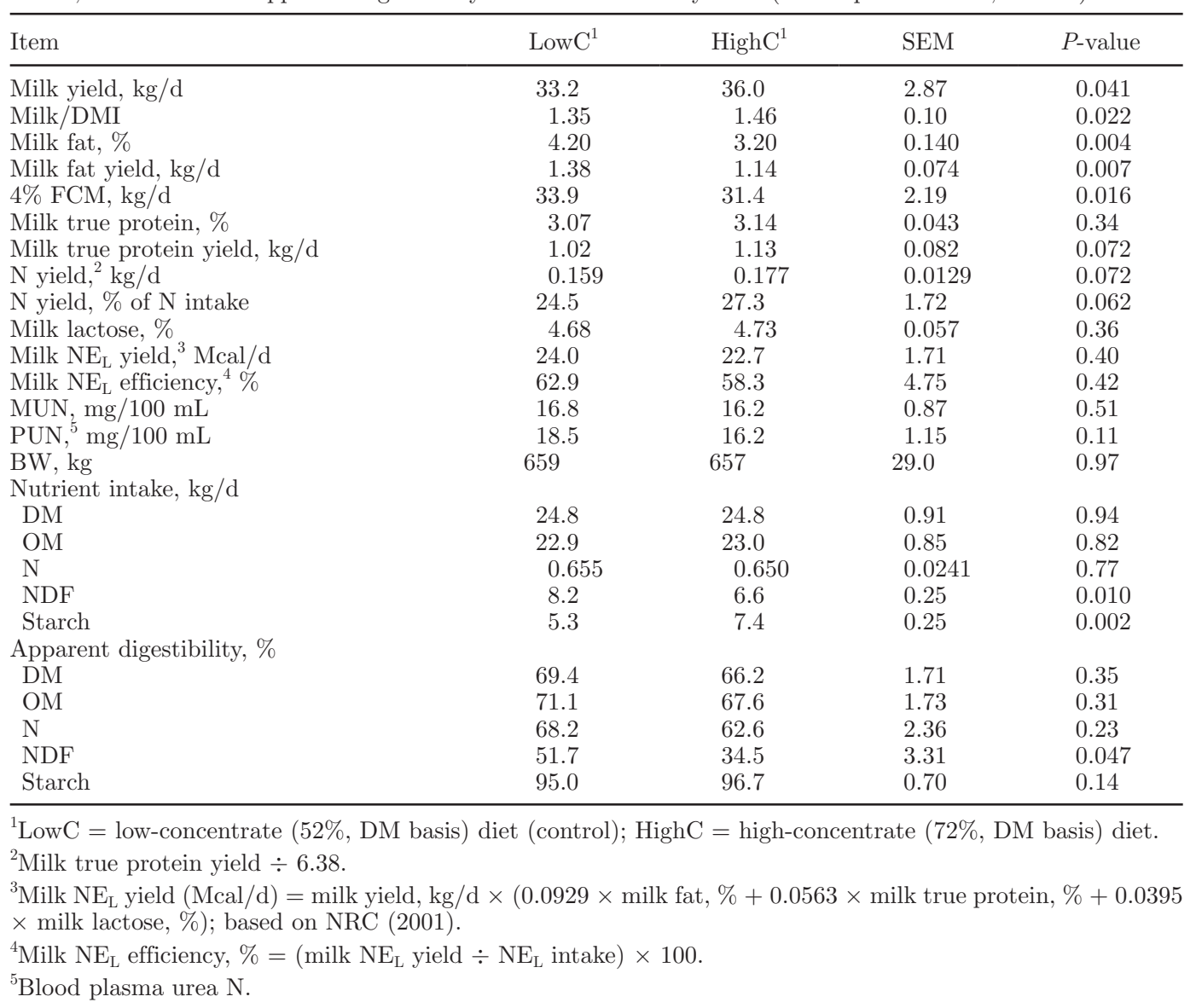

relate ruminal microbial growth to carbohydrate availability (Vérité and Peyraud, 1989; AFRC, 1992; Russell et al., 1992; NRC, 2001). Some of these systems (AFRC, 1992; NRC, 2001) consider the possibility of RDP limiting microbial growth. In a recent meta-analysis of more than 1,700 diets, however, we demonstrated that ruminal protein degradability had no effect on milk protein yield, and NRC (2001) is likely overestimating the RDP requirements of lactating dairy cows (Huhtanen and Hristov, 2009). Thus, energy remains the most important dietary factor determining the intensity and efficiency of microbial protein synthesis in the rumen.

Ammonia concentration in the rumen was significantly reduced by HighC in this experiment, which confirms our previous observations that provision of fermentable carbohydrates can reduce ammonia production (by reducing deamination and enhancing microbial capture of released amino acids) or enhance microbial capture of released ammonia in the rumen (Hristov et al., 2005). Increasing the concentrate:forage ratio from 20:80 to 65:35 in the diet of lactating dairy cows, however, was reported to increase ruminal ammonia concentration and urinary $\mathrm{N}$ losses (Moorby et al., 2006). These ef-

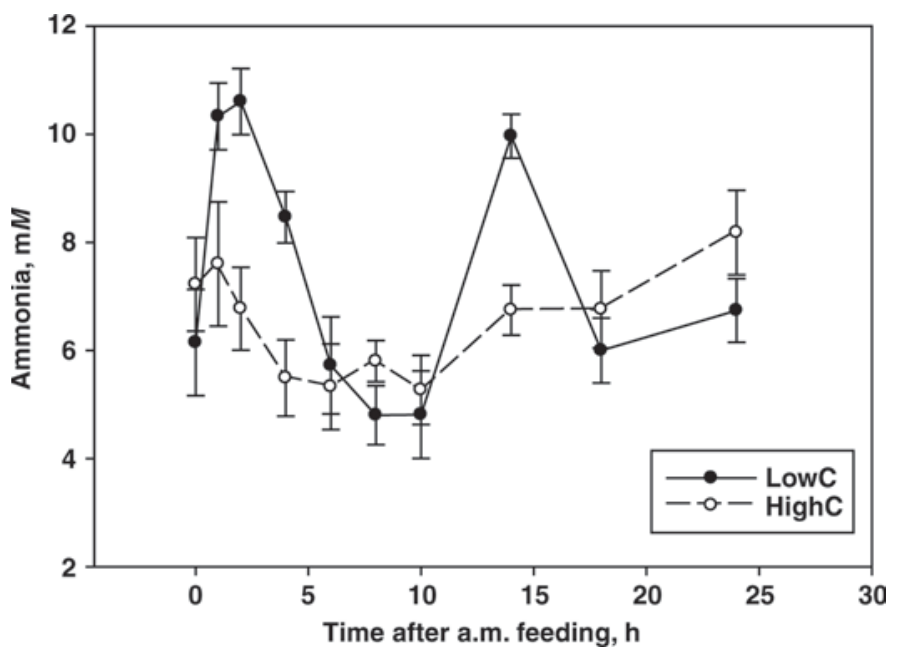

Figure 2. Effect of dietary concentrate on ruminal ammonia concentration in dairy cows (means $\pm \mathrm{SE} ; \mathrm{n}=120$ ). LowC $=$ low-concentrate $(52 \%, \mathrm{DM}$ basis) diet (control); HighC $=$ high-concentrate $(72 \%$, DM basis) diet. Overall treatment effect, $P=0.018$; treatment $\times$ time interaction, $P<0.001$. 
Table 4. Effect of dietary concentrate on urinary and fecal $\mathrm{N}$ losses in dairy cows (least squares means; $\mathrm{n}=$ 12)

\begin{tabular}{|c|c|c|c|c|}
\hline Item & LowC $^{1}$ & $\operatorname{HighC}^{1}$ & SEM & $P$-value \\
\hline \multicolumn{5}{|l|}{ Urinary N } \\
\hline $\mathrm{kg} / \mathrm{d}$ & 0.233 & 0.227 & 0.0099 & 0.67 \\
\hline As $\%$ of $\mathrm{N}$ intake & 35.5 & 35.3 & 1.96 & 0.91 \\
\hline As $\%$ of total $\mathrm{N}$ excreted & 52.7 & 48.8 & 1.19 & 0.18 \\
\hline \multicolumn{5}{|l|}{ Fecal N } \\
\hline $\mathrm{kg} / \mathrm{d}$ & 0.209 & 0.239 & 0.0146 & 0.27 \\
\hline As $\%$ of $\mathrm{N}$ intake & 31.8 & 37.4 & 2.36 & 0.23 \\
\hline \multicolumn{5}{|l|}{ Total N excretion } \\
\hline $\mathrm{kg} / \mathrm{d}$ & 0.442 & 0.466 & 0.0237 & 0.48 \\
\hline As $\%$ of $\mathrm{N}$ intake & 67.4 & 72.6 & 4.02 & 0.38 \\
\hline
\end{tabular}

fects can be easily explained by the linear increase in $\mathrm{N}$ intake (from 0.303 to $0.603 \mathrm{~g} / \mathrm{d}$ ) with increasing the concentrate:forage ratio in the Moorby et al. (2006) study compared with the current experiment, in which HighC and LowC diets had similar N concentration. Others did not find an effect on ruminal ammonia concentration with increasing dietary concentrate inclusion (Yang et al., 2001; Rotger et al., 2006; CantalapiedraHijar et al., 2009).

Similar to the current experiment, enhanced propionate concentration in the rumen of cows fed high-grain compared with high-forage diets has typically been reported in the literature (Bauman et al., 1971; Oshio et al., 1987; Sutton et al., 2003). Sutton et al. (2003) also reported a very close correlation between propionate (and the other major VFA) net production rate and concentration in ruminal fluid. Greater propionate production may trigger an increase in gluconeogenesis and milk production response (Danfaer, 1994). With a limited number of cows and apparent sampling issues Wieghart et al. (1986), however, reported no effect of a large increase in concentrate:forage ratio (from 35:65 to 80:20) on glucose fluxes across the gut and liver in lactating dairy cows. Surprisingly, Moorby et al. (2006)

Table 5. Effect of dietary concentrate on ${ }^{15} \mathrm{~N}$ enrichment of various $\mathrm{N}$ pools and ${ }^{15} \mathrm{~N}$ calculations in dairy cows (least squares means; $\mathrm{n}=287$, ${ }^{15} \mathrm{~N}$ enrichment of MPN; $\mathrm{n}=115$ and $120,{ }^{15} \mathrm{~N}$ enrichment of $\mathrm{NH}_{3}-\mathrm{N}$ and $\mathrm{BN}$, respectively; and $\mathrm{n}=12$, all other variables)

\begin{tabular}{|c|c|c|c|c|}
\hline Item & LowC $^{1}$ & HighC $^{1}$ & SEM & $P$-value \\
\hline${ }^{15} \mathrm{~N}$ enrichment of $\mathrm{NH}_{3}-\mathrm{N}, \mathrm{APE}^{2}$ & 0.767 & 0.617 & 0.0903 & $0.15^{3}$ \\
\hline${ }^{15} \mathrm{~N}$ enrichment of $\mathrm{BN},{ }^{4} \mathrm{APE}$ & 0.128 & 0.135 & 0.0325 & $0.82^{3}$ \\
\hline${ }^{15} \mathrm{~N}$ enrichment of $\mathrm{MPN},{ }^{5} \mathrm{APE}$ & 0.0083 & 0.0087 & 0.00018 & $0.20^{3}$ \\
\hline $\mathrm{AUC}, \mathrm{BN}$ & 2.02 & 2.18 & 0.136 & 0.25 \\
\hline AUC, MPN & 0.98 & 0.96 & 0.060 & 0.86 \\
\hline $\mathrm{BN}$ from $\mathrm{NH}_{3}-\mathrm{N},{ }^{7} \%$ & 49.6 & 54.0 & 3.67 & 0.20 \\
\hline $\begin{array}{l}\text { As g of } N / d \\
\text { As } \% \text { of } N \text { intake }\end{array}$ & 501 & 500 & 340 & \\
\hline Ruminal $\mathrm{NH}_{3}-\mathrm{N}$ flux & $\begin{array}{l}50.1 \\
458\end{array}$ & $\begin{array}{l}50.0 \\
276\end{array}$ & $\begin{array}{c}3.49 \\
44.5\end{array}$ & $\begin{array}{l}0.98 \\
0.011\end{array}$ \\
\hline As $\mathrm{g} / \mathrm{d}$ & & & & \\
\hline As \% of $\mathrm{N}$ intake & 70.6 & 42.4 & 6.94 & 0.012 \\
\hline Recycled $\mathrm{NH}_{3}-\mathrm{N}, \mathrm{g} / \mathrm{d}$ & 178 & 141 & 20.2 & 0.39 \\
\hline
\end{tabular}

${ }^{1}$ LowC $=$ low-concentrate $(52 \%$, DM basis $)$ diet (control); HighC = high-concentrate $(72 \%$, DM basis $)$ diet.

${ }^{2}$ Atom percent excess.

${ }^{3}$ Treatment $\times$ time interactions: $\mathrm{NH}_{3}-\mathrm{N}, P=0.010 ; \mathrm{BN}, P=0.23 ; \mathrm{MPN}, P=0.55$.

${ }^{4}$ Bacterial N

${ }^{5}$ Milk protein $\mathrm{N}$.

${ }^{6}$ Area under the ${ }^{15} \mathrm{~N}$ curve, APE $\times$ h.

${ }^{7}$ Calculated as $\left(\mathrm{AUC}_{\text {rumen bacteria }} \div \mathrm{AUC}_{\text {rumen ammonia }}\right) \times 100 ;\left(\mathrm{AUC}_{\text {milk protein }} \div \mathrm{AUC}_{\text {rumen bacteria }}\right) \times 100$; or $\left(\mathrm{AUC}_{\text {milk protein }} \div \mathrm{AUC}_{\text {rumen ammonia }}\right) \times 100$, respectively.

${ }^{8}$ Proportion of the irreversible loss of ammonia $\mathrm{N}$ leaving the rumen as microbial $\mathrm{N}(\mathrm{MN})$. Calculated as [(MN flow $\times$ proportion of bacterial $\mathrm{N}$ derived from ammonia $\mathrm{N}) \div$ irreversible loss of ammonia $\mathrm{N}] \times 100$. 


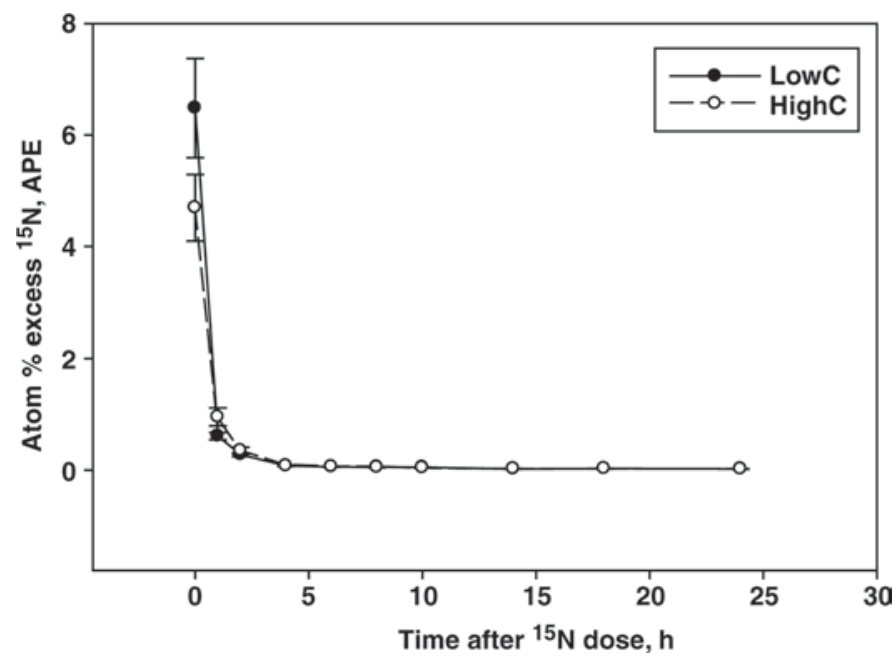

Figure 3. Effect of dietary concentrate on ${ }^{15} \mathrm{~N}$-enrichment of ruminal ammonia $\mathrm{N}$ in dairy cows (means $\pm \mathrm{SE} ; \mathrm{n}=115$ ). LowC $=$ lowconcentrate $(52 \%$, DM basis) diet (control); HighC $=$ high-concentrate (72\%, DM basis) diet. Overall treatment effect, $P=0.15$; treatment $\times$ time interaction, $P=0.010$.

reported linear increases in total VFA and butyrate concentrations and a decrease in acetate with increasing proportion of concentrate in dietary DM, but concentration of propionate was not affected.

Methane production in the rumen was not affected by concentrate level in this experiment although forage:concentrate ratio is known to have a major effect on ruminal gas production (Hungate, 1966). Increasing dietary concentrate has been demonstrated to have a significant effect on enteric methane production on an individual animal or production system scale (Lovett et al., 2003, 2006) and is among the most effective management practices recommended for mitigating greenhouse gas emissions from ruminants (Boadi et al., 2004). Methane production rate for HighC was consistently lower throughout the sampling period (data not shown), but did not reach statistical significance because of large variability in the data.

In spite of the increased starch intake, microbial protein production in the rumen was not affected by diet in this experiment. The stimulatory effect of concentrate feeds on the ruminal microflora is well documented and, according to Hungate (1966), is a result of the greater and more rapid digestibility of concentrates versus forages. A high concentration of glucose in the rumen has been shown to decrease fiber-digesting bacteria via the production of inhibitory compounds (Russell, 1993). Although fibrolytic species may be inhibited by highconcentrate diets, the rest of the ruminal microflora increases in numbers (Oshio et al., 1987). When the diet is deficient in ruminally fermentable substrate, carbohydrate supplementation enhances microbial pro- tein synthesis and production, irrespective of the type of carbohydrate (Hristov et al., 2005; Broderick et al., 2008). Urinary PD excretion was increased by increasing the proportion of dietary concentrate in the Moorby et al. (2006) study, suggesting enhanced microbial protein synthesis and outflow from the rumen. Cows in their experiment, however, increased DM and energy intake linearly as dietary concentrate:forage ratio increased, which alone would explain the estimated increase in microbial protein outflow from the rumen. It appears that the LowC diet in the current study did not limit microbial growth and therefore, the rumen ecosystem did not respond to the additional substrate provided with HighC. Negative associative effects of fermentable carbohydrates and fiber degradability in the rumen (Huhtanen, 1987; Firkins, 1997) are the most likely reason for the observed decreased total-tract NDF digestibility. Similar depression of fiber digestibility with high concentrate diets was reported by Moorby et al. (2006). Ruminal fibrolytic activities were similar among treatments in the current study, but it appears that, due to large circadian and between-animal variability in ruminal enzyme activities (Hristov and Ropp, 2003; Hristov et al., 2005), this multi-step assay may not reliably represent the true microbial activities in ruminal contents.

The HighC diet reduced ruminal ammonia flux compared with LowC. The significant reduction in ammonia flux and the reduced ruminal ammonia concentration with HighC resulted in enhanced efficiency of utilization of ruminal ammonia $\mathrm{N}$ for milk protein synthesis. The improved overall milk $\mathrm{N}$ efficiency with this diet,

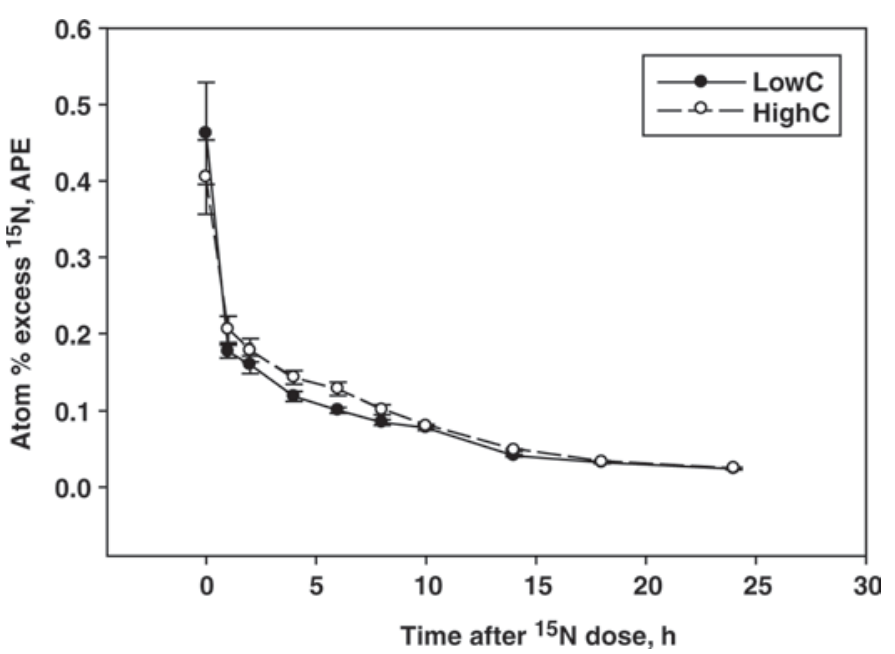

Figure 4. Effect of dietary concentrate on ${ }^{15} \mathrm{~N}$-enrichment of ruminal bacterial $\mathrm{N}$ in dairy cows (means $\pm \mathrm{SE} ; \mathrm{n}=120$ ). Low $\mathrm{C}=$ lowconcentrate $(52 \%, \mathrm{DM}$ basis) diet (control); HighC $=$ high-concentrate $(72 \%, \mathrm{DM}$ basis) diet. Overall treatment effect, $P=0.82$; treatment $\times$ time interaction, $P=0.23$. 


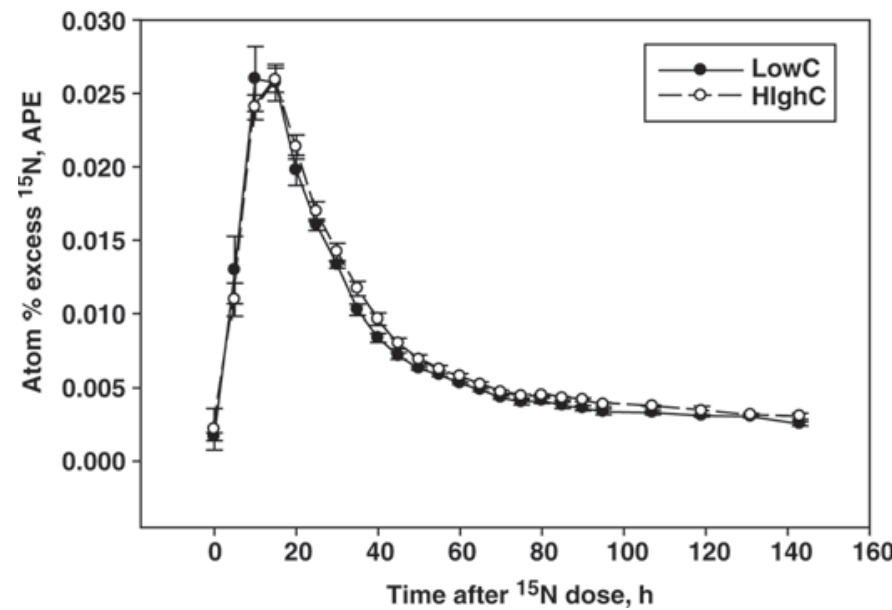

Figure 5. Effect of dietary concentrate on ${ }^{15} \mathrm{~N}$-enrichment of milk protein $\mathrm{N}$ in dairy cows (means $\pm \mathrm{SE} ; \mathrm{n}=287$ ). LowC $=$ low concentrate $(52 \%, \mathrm{DM}$ basis) diet (control); HighC $=$ high concentrate $(72 \%$, $\mathrm{DM}$ basis) diet. Overall treatment effect, $P=0.20$; treatment $\times$ time interaction, $P=0.55$

however, did not correspond to a reduction in urinary N losses. In dairy heifers, Zanton and Heinrichs (2009) found no significant differences in dietary $\mathrm{N}$ utilization between low (22 to $24 \%$ NDF, DM basis) and high forage (40 to $42 \% \mathrm{NDF}$ ) diets. The HighC diet resulted in numerically greater utilization of ruminal ammonia $\mathrm{N}$ for microbial protein synthesis, but large variability among animals did not allow these differences to reach statistical significance. In an abstract, Al-Dehneh

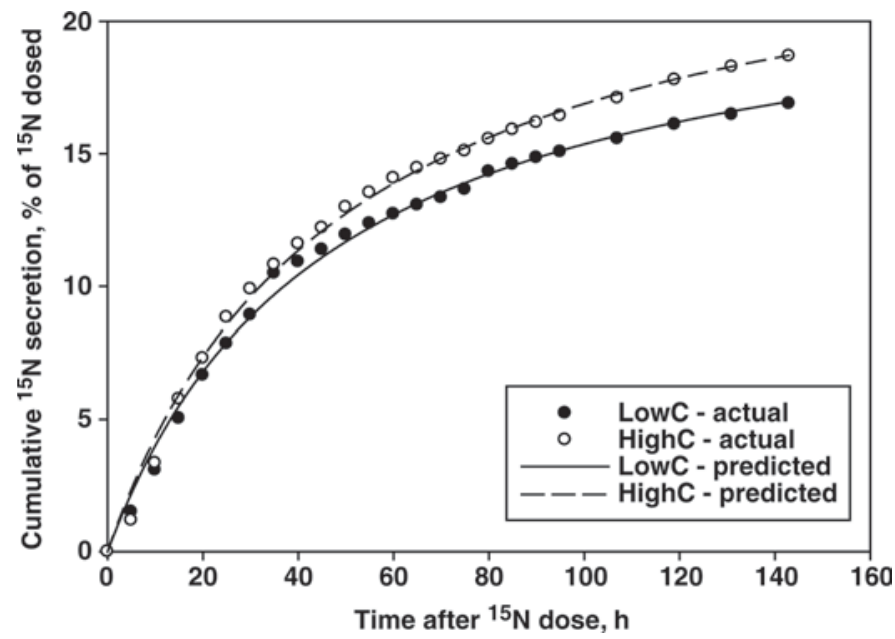

Figure 6. Effect of dietary concentrate on cumulative secretion of ${ }^{15} \mathrm{~N}$ in milk protein (as percentage of ${ }^{15} \mathrm{~N}$ dosed intraruminally). Symbols are measured and lines are predicted values (single rectangular 2-parameter hyperbola model). LowC $=$ low-concentrate $(52 \%$, $\mathrm{DM}$ basis) diet (control); HighC $=$ high-concentrate $(72 \%, \mathrm{DM}$ basis $)$ diet. Theoretical maximum of ${ }^{15} \mathrm{~N}$ secreted in milk (as \% of dosed; estimate \pm approx. SE; $\mathrm{n}=288$ ): $22.4 \pm 2.18$ and $25.0 \pm 1.53$, LowC and HighC, respectively $(P=0.16)$. Differences between ${ }^{15} \mathrm{~N}$ secretion lines: LowC vs. HighC, $P=0.009$. et al. (1986) also reported greater incorporation of $\mathrm{N}$ recycled to the rumen into bacterial protein with a high concentrate (1:2 forage:concentrate ratio) versus a low concentrate (2:1, forage:concentrate ratio) diet. The HighC diet resulted in considerably greater proportion of bacterial $\mathrm{N}$ in duodenal digesta $\mathrm{N}$, implying greater microbial protein synthesis in the rumen.

The LowC diet did not limit production in this experiment (according to NRC, 2001), but at the same DMI, the HighC diet increased milk yield by $2.8 \mathrm{~kg}$ of milk/d. Increased production with increased concentrate feeding has been consistently reported in lactating dairy cows. Moorby et al. (2006), for example, observed a nearly $8 \mathrm{~kg} / \mathrm{d}$ increase in milk yield in response to increasing the dietary concentrate:forage ratio from 20:80 to $65: 35$, but as indicated earlier, this was mostly due to increased DM and energy intake. A similar increase in milk yield with increased dietary concentrate was reported by others (Mayne and Gordon, 1984; Hansen et al., 1991; Rinne et al., 1999; Kuoppala et al., 2004). Milk fat concentration was significantly decreased by HighC in the current experiment. This effect has been commonly reported for high concentrate diets (Hansen et al., 1991; Yang et al., 2001; Moorby et al., 2006) and is clearly an indication of milk fat depression due to ruminal processes (Van Soest, 1963; Bauman et al., 2008).

We hypothesized that possible improvement in ruminal ammonia utilization with greater concentrate

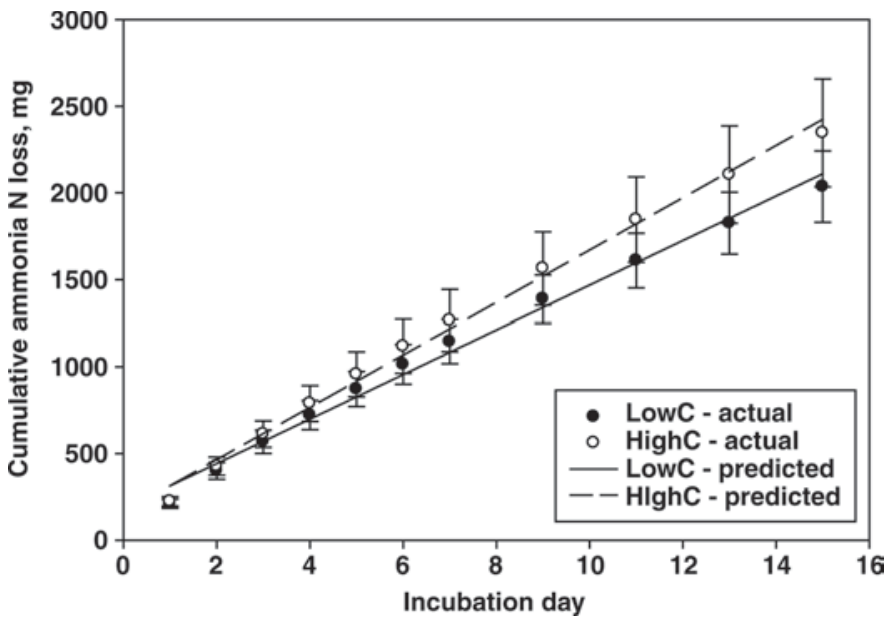

Figure 7. Effect of dietary concentrate on cumulative ammonia N losses from dairy manure. Symbols are measured (means $\pm \mathrm{SE}$ ) and lines are predicted values (linear regression). LowC $=$ low-concentrate (52\%, DM basis) diet (control); HighC = high-concentrate (72\%, DM basis) diet. End-point (d 15) cumulative ammonia $\mathrm{N}$ emission ( $\mathrm{n}=$ 12; $P=0.029$ ): 2,035 and 2,345 $\mathrm{mg}$ (LowC and HighC, respectively; $\mathrm{SEM}=217.5)$. Regression analysis $(\mathrm{n}=132)$ : diet effect, $P=0.014$; diet $\times$ incubation day interaction, $P<0.001$. Slope: 128 and $151 \mathrm{mg}$ of ammonia N/d (respectively; SEM $=10.2 ; P<0.001$. Regression lines: $P<0.001$. 
inclusion in the diet would result in reduced ammonia emissions from manure. The HighC diet, however, had no effect on urinary $\mathrm{N}$ output, which is the main source of ammonia N emitted from manure (Bussink and Oenema, 1998). Thus, the lack of effect on ammonia losses with HighC is not surprising. This diet in fact increased the ammonia emitting potential of manure. Research with dairy heifers has shown a similar lack of effect of high concentrate diets on either $\mathrm{N}$ losses (Zanton and Heinrichs, 2009) or ammonia emission off the barn floor (Lascano et al., 2008).

\section{CONCLUSIONS}

In this experiment, increased concentrate proportion in the diet of dairy cows resulted in reduced ruminal ammonia concentration and enhanced ammonia utilization for milk protein synthesis. However, these effects did not reduce urinary $\mathrm{N}$ losses and only marginally improved milk $\mathrm{N}$ efficiency. The increased energy intake with the high concentrate diet increased milk yield, but decreased fiber digestibility, milk fat percentage, and $4 \%$ FCM yield. Increasing dietary concentrate was not a successful strategy for mitigating either enteric methane production or ammonia emission from manure.

\section{ACKNOWLEDGMENTS}

This study was supported by funds from the Idaho Dairymen's Association (Boise) and the University of Idaho Agricultural Experiment Station (Boise). The authors thank V. Borek (Department of Plant, Soil, and Entomological Sciences, University of Idaho) for conducting the methane analyses, W. Price (Statistical Programs, College of Agricultural and Life Sciences, University of Idaho) for assistance with statistical evaluation of the results, and the staff of the Department of Animal and Veterinary Science Dairy Center (Moscow, ID) for their conscientious care of the experimental cows.

\section{REFERENCES}

AFRC (Agricultural and Food Research Council). 1992. Nutritive Requirements of Ruminant Animals: Protein. Technical Committee on Responses to Nutrients, Report No. 9. Nutrition Abstracts and Reviews, Series B 62:787-835. CAB International, Wallingford, UK.

Al-Dehneh, A., R. Wanderley, C. B. Theurer, and J. T. Huber. 1986. Recycled nitrogen in dairy cows fed different amount of concentrate. J. Dairy Sci. 69(Suppl. 1):219. (Abstr.)

AOAC. 2000. Official Methods of Analysis. 17th ed. AOAC, Arlington, VA.

APHA (American Public Health Association). 1998. Standard methods for the Examination of Water and Wastewater. 20th ed. S. C. Lenore, A. E. Greenberg, and A. D. Eaton, ed. American Public Health Association, Washington, DC.
Bauman, D. E., C. L. Davis, and H. F. Bucholtz. 1971. Propionate production in the rumen of cows fed either a control or high-grain, low-fiber diet. J. Dairy Sci. 54:1282-1287.

Bauman, D. E., J. W. Perfield II, K. J. Harvatine, and L. H. Baumgard. 2008. Regulation of fat synthesis by CLA: Lactation and the ruminant model. J. Nutr. 138:403-409.

Boadi, D., C. Benchaar, J. Chiquette, and D. Massé. 2004. Mitigation strategies to reduce enteric methane emissions from dairy cows: Update review. Can. J. Anim. Sci. 84:319-335.

Broderick, G. A., N. D. Luchini, S. M. Reynal, G. A. Varga, and V. A. Ishler. 2008. Effect on production of replacing dietary starch with sucrose in lactating dairy cows. J. Dairy Sci. 91:4801-4810.

Bussink, D. W., and O. Oenema. 1998. Ammonia volatilization from dairy farming systems in temperate areas: A review. Nutr. Cycl. Agroecosyst. 51:19-33.

Cantalapiedra-Hijar, G., D. R. Yáñez-Ruiz, A. I. Martín-García, and E. Molina-Alcaide. 2009. Effects of forage:concentrate ratio and forage type on apparent digestibility, ruminal fermentation, and microbial growth in goats. J. Anim. Sci. 87:622-631.

Chen, X. B. 1989. Excretion of purine derivatives by sheep and cattle and its use for estimation of absorbed microbial protein. $\mathrm{PhD}$ Thesis. University of Aberdeen, UK.

Chen, X. B., Y. K. Chen, M. F. Franklin, E. R. Ørskov, and W. J. Shand. 1992. The effect of feed intake and body weight on purine derivative excretion and microbial protein supply in sheep. J. Anim. Sci. 70:1534-1542.

Danfaer, A. 1994. Nutrient metabolism and utilization in the liver. Livest. Prod. Sci. 34:115-127.

Firkins, J. L. 1997. Effects of feeding nonforage fiber sources on site of fiber digestion. J. Dairy Sci. 80:1426-1437.

Foley, A. E., A. N. Hristov, A. Melgar, J. K. Ropp, R. P. Etter, S. Zaman, C. W. Hunt, K. Huber, and W. J. Price. 2006. Effect of barley and its amylopectin content on ruminal fermentation and nitrogen utilization in lactating dairy cows. J. Dairy Sci. 89:4321-4335.

Hansen, W. P., D. E. Otterby, J. G. Linn, and J. D. Donker. 1991. Influence of forage type, ratio of forage to concentrate, and methionine hydroxy analog on performance of dairy cows. J. Dairy Sci. 74:1361-1369.

Hristov, A. N., T. A. McAllister, and K. J. Cheng. 1997. Effect of carbohydrate level and ammonia availability on utilization of $\alpha$-amino nitrogen by mixed ruminal microorganisms in vitro. Proc. Western Section Am. Soc. Anim. Sci. 48:186-189.

Hristov, A. N., T. A. McAllister, and K.-J. Cheng. 1998. Effect of dietary or abomasal supplementation of exogenous polysaccharidedegrading enzymes on rumen fermentation and nutrient digestibility. J. Anim. Sci. 76:3146-3156.

Hristov, A. N., T. A. McAllister, F. H. Van Herk, K.-J. Cheng, C. J. Newbold, and P. R. Cheeke. 1999. Effect of Yucca schidigera on ruminal fermentation and nutrient digestion in heifers. J. Anim. Sci. $77: 2554-2563$.

Hristov, A. N., and J. K. Ropp. 2003. Effect of dietary carbohydrate composition and availability on utilization of ruminal ammonia nitrogen for milk protein synthesis in dairy cows. J. Dairy Sci. 86:2416-2427.

Hristov, A. N., J. K. Ropp, K. L. Grandeen, S. Abedi, R. P. Etter, A. Melgar, and A. E. Foley. 2005. Effect of carbohydrate source on ammonia utilization in lactating dairy cows. J. Anim. Sci. $83: 408-421$.

Hristov, A. N., M. Vander Pol, M. Agle, S. Zaman, C. Schneider, P. Ndegwa, V. K. Vaddella, K. Johnson, K. J. Shingfield, and S. K. R. Karnati. 2009. Effect of lauric acid and coconut oil on ruminal fermentation, digestion, ammonia losses from manure, and milk fatty acid composition in lactating cows. J. Dairy Sci. 92:55615582.

Huhtanen, P. 1987. The effects of intraruminal infusions of sucrose and xylose on nitrogen and fibre digestion in the rumen and intestines of cattle receiving diets of grass silage and barley. J. Agric. Sci. Finl. 59:405-424. 
Huhtanen, P., and A. N. Hristov. 2009. A meta-analysis of the effects of protein concentration and degradability on milk protein yield and milk $\mathrm{N}$ efficiency in dairy cows. J. Dairy Sci. 92:3222-3232.

Hungate, R. E. 1966. The Rumen and its Microbes. Academic Press, New York, NY.

Isaacson, H. R., F. C. Hinds, M. P. Bryant, and F. N. Owens. 1975. Efficiency of energy utilization by mixed rumen bacteria in continuous culture. J. Dairy Sci. 58:1645-1659.

Johnson, K. A., M. T. Huyler, H. H. Westberg, B. K. Lamb, and P. Zimmerman. 1994. Measurement of methane emissions from ruminant livestock using a $\mathrm{SF}_{6}$ tracer technique. Environ. Sci. Technol. 28:359-362.

Kuoppala, K., S. Yrjänen, S. Jaakkola, R. Kangasniemi, J. Sariola, and H. Khalili. 2004. Effects of increasing concentrate energy supply on the performance of loose-housed dairy cows fed grass silage-based diets. Livest. Prod. Sci. 85:15-26.

Lascano, G. J., G. I. Zanton, M. L. Moody, P. A. Topper, E. F. Wheeler, and A. J. Heinrichs. 2008. Short communication: Effect of changing the ratio of forage to concentrate on ammonia emissions by dairy heifers. J. Dairy Sci. 91:4301-4306.

Lovett, D. K., S. Lovell, L. Stack, J. Callan, M. Finlay, J. Conolly, and F. P. O'Mara. 2003. Effect of forage/concentrate ratio and dietary coconut oil level on methane output and performance of finishing beef heifers. Livest. Prod. Sci. 84:135-146.

Lovett, D. K., L. Shalloo, P. Dillon, and F. P. O'Mara. 2006. A systems approach to quantify greenhouse gas fluxes from pastoral dairy production as affected by management regimen. Agric. Syst. $88: 156-179$.

Mayne, C. S., and F. J. Gordon. 1984. The effect of type of concentrate and level of concentrate feeding on milk production. Anim. Prod. 39:65-76.

McCleary, B. V., V. Solah, and T. S. Gibson. 1994. Quantitative measurement of total starch in cereal flours and products. J. Cereal Sci. 20:51-58

McDougall, E. I. 1948. The composition and output of sheep's saliva. Biochem. J. 43:99-109.

Misselbrook, T. H., J. M. Powell, G. A. Broderick, and J. H. Grabber. 2005. Dietary manipulation in dairy cattle: Laboratory experiments to assess the influence of ammonia emissions. J. Dairy Sci. $88: 1765-1777$.

Moorby, J. M., R. J. Dewhurst, R. T. Evans, and J. L. Danelón. 2006. Effects of dairy cow diet forage proportion on duodenal nutrient supply and urinary purine derivative excretion. J. Dairy Sci. 89:3552-3562.

Ndegwa, P. M., V. K. Vaddella, A. N. Hristov, and H. S. Joo. 2009 Measuring concentrations of ammonia in ambient air or exhaust air stream using acid traps. J. Environ. Qual. 38:647-653.

Newbold, J. R., and S. R. Rust. 1992. Effects of asynchronous nitrogen and energy supply on growth of ruminal bacteria in batch culture. J. Anim. Sci. 70:538-546.

Nocek, J. E., and J. B. Russell. 1988. Protein and energy as an integrated system. Relationship of ruminal protein and carbohydrate availability to microbial synthesis and milk production. J. Dairy Sci. 71:2070-2107.

Nolan, J. V. 1975. Quantitative models of nitrogen metabolism in sheep. Pages 416-431 in Digestion and Metabolism in the Ruminant. I. W. McDonald and A. C. I. Warner, ed. The University of New England Publishing Unit, Armidale, Australia

NRC. 2001. Nutrient Requirements of Dairy Cattle. 7th rev. ed. National Academy Press, Washington, DC.

Oshio, S., I. Tahata, and H. Minato. 1987. Effect of diets differing in ratios of roughage to concentrate on microflora in the rumen of heifers. J. Gen. Appl. Microbiol. 33:99-111.

Pilgrim, A. F., F. V. Gray, R. A. Weller, and C. B. Belling. 1970. Synthesis of microbial protein from ammonia in sheep's rumen and proportion of dietary nitrogen converted to microbial nitrogen. Br. J. Nutr. 24:589-598.

Rinne, M., S. Jaakkola, K. Kaustell, T. Heikkilä, and P. Huhtanen. 1999. Silages harvested at different stages of grass growth v. concentrate foods as energy and protein sources in milk production. Anim. Sci. 69:251-263.
Rotger, A., A. Ferret, S. Calsamiglia, and X. Manteca. 2006. In situ degradability of seven plant protein supplements in heifers fed high concentrate diets with different forage to concentrate ratio. Anim. Feed Sci. Technol. 125:73-87.

Russell, J. B. 1993. Glucose toxicity in Prevotella ruminicola: Methylglyoxal accumulation and its effect on membrane physiology. Appl. Environ. Microbiol. 59:2844-2850.

Russell, J. B., J. D. O'Connor, D. G. Fox, P. J. Van Soest, and C. J. Sniffen. 1992. A net carbohydrate and protein system for evaluating cattle diets: I. Ruminal fermentation. J. Anim. Sci. 70:3551-3561.

Russell, J. B., C. J. Sniffen, and P. J. Van Soest. 1983. Effect of carbohydrate limitation on degradation and utilization of casein by mixed rumen bacteria. J. Dairy Sci. 66:763-775.

Shi, Y., D. B. Parker, N. A. Cole, B. W. Auvermann, and J. E. Mehlhorn. 2001. Surface amendments to minimize ammonia emissions from beef cattle feedlots. Trans. ASAE 44:677-682.

Strobel, H. J., and J. B. Russell. 1986. Effects of pH and energy on bacterial protein synthesis by carbohydrate-limited cultures of mixed rumen bacteria. J. Dairy Sci. 69:2941-2947.

Sutton, J. D., M. S. Dhanoa, S. V. Morant, J. France, D. J. Napper, and E. Schuller. 2003. Rates of production of acetate, propionate, and butyrate in the rumen of lactating dairy cows given normal and low-roughage diets. J. Dairy Sci. 86:3620-3633.

Tamminga, S. 1992. Nutrition management of dairy cows as a contribution to pollution control. J. Dairy Sci. 75:345-357.

Udén, P., P. E. Colucci, and P. J. Van Soest. 1980. Investigation of chromium, cerium, and cobalt as markers in digesta. Rate of passage studies. J. Sci. Food Agric. 31:625-632.

USEPA (US Environmental Protection Agency). 2004. National Emission Inventory-Ammonia Emissions from Animal Husbandry Operations. US EPA, Washington, DC.

Valadares, R. F. D., G. A. Broderick, S. C. Valadares Filho, and M. K. Clayton. 1999. Effect of replacing alfalfa silage with high moisture corn on ruminal protein synthesis estimated from excretion of total purine derivatives. J. Dairy Sci. 82:2686-2696.

Van Keulen, J., and B. A. Young. 1977. Evaluation of acid-insoluble ash as a natural marker in ruminant digestibility studies. J. Anim. Sci. $44: 282-287$.

Van Soest, P. J. 1963. Ruminant fat metabolism with particular reference to factors affecting low milk fat and feed efficiency. A review. J. Dairy Sci. 46:204-216.

Van Soest, P. J., J. B. Robertson, and B. A. Lewis. 1991. Methods for dietary fiber, neutral detergent fiber, and nonstarch polysaccharides in relation to animal nutrition. J. Dairy Sci. 74:3583-3597.

Vander Pol, M., A. N. Hristov, S. Zaman, and N. Delano. 2008a. Peas can replace soybean meal and corn grain in dairy cow diets. J. Dairy Sci. 91:698-703.

Vander Pol, M., A. N. Hristov, S. Zaman, N. Delano, and C. Schneider. 2008b. Effect of inclusion of peas in dairy cow diets on ruminal fermentation, digestibility, and nitrogen losses. Anim. Feed Sci. Technol. 150:95-105.

Verbic, J., X. B. Chen, N. A. Macleod, and E. R. Ørskov. 1990. Excretion of purine derivatives by ruminants: Effect of microbial nucleic acid infusion on purine derivative excretion by steers. J. Agric. Sci. 114:243-248.

Vérité, R., and J.-L. Peyraud. 1989. Protein: The PDI system. Pages 33-48 in Ruminant Nutrition. Recommended Allowances and Feed Tables. R. Jarrige, ed. INRA, Nouzilly, France.

Wieghart, M., R. Slepetis, J. M. Elliot, and D. F. Smith. 1986. Glucose absorption and hepatic gluconeogenesis in dairy cows fed diets varying in forage content. J. Nutr. 116:839-850.

Yang, W. Z., K. A. Beauchemin, and L. M. Rode. 2001. Effects of grain processing, forage to concentrate ratio, and forage particle size on rumen $\mathrm{pH}$ and digestion by dairy cows. J. Dairy Sci. $84: 2203-2216$.

Zanton, G. I., and A. J. Heinrichs. 2009. Digestion and nitrogen utilization in dairy heifers limit-fed a low or high forage ration at four levels of nitrogen intake. J. Dairy Sci. 92:2078-2094. 